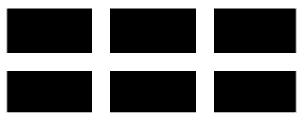

ThE WiLliam DAVIDSON INSTITUTE AT THE UNIVERSITY OF MICHIGAN BUSINESS SCHOOL

\title{
Internet Entrepreneurship: Networks and Performance of Internet Ventures In China
}

\author{
By: Bat Batjargal \\ William Davidson Institute Working Paper Number 753 \\ February 2005
}


INTERNET ENTREPRENEURSHIP: NETWORKS AND

PERFORMANCE OF INTERNET VENTURES IN CHINA

\author{
BAT BATJARGAL * \\ Harvard University \\ Davis Center for Russian and Eurasian Studies \\ 625 Massachusetts Avenue \\ Cambridge, MA 02139 \\ Email: batjarg@fas.harvard.edu \\ Peking University \\ Guanghua School of Management \\ Beijing, 100781 \\ China \\ Email: batjargal@gsm.pku.edu.cn
}

${ }^{*}$ I thank Kathy He, Joe Hu, Erin Huang, Jessica Lee, Michael Sun, Tim Wang, Vivienne Wu,
and Edward Zhang for their excellent research assistance. I am grateful to Larry Farh, Joseph
Galaskiewicz, Michael Hitt, and Anne Tsui for constructive comments and suggestions on early
versions. I appreciate support of Weiying Zhang and Celine Shen. Financial support of the
Guanghua School of Management and Center for E-Commerce of Peking University are
gracefully acknowledged. 


\title{
INTERNET ENTREPRENEURSHIP: NETWORKS AND PERFORMANCE OF INTERNET VENTURES IN CHINA
}

\begin{abstract}
This article examines the contingent value of entrepreneurs' networks to survival likelihood of Internet ventures, and the dynamics of entrepreneurs' networks over time. The empirical data are composed of the longitudinal surveys of 94 Internet ventures in Beijing, China. The study found the positive and the negative contingent effects of structural holes on the survival likelihood of new firms. The study found that networking skills of entrepreneurs are associated positively with the changes in networks over time. Improved social skills lead to greater firm legitimacy.
\end{abstract}

Key words: Structural holes, human capital, Internet, entrepreneurship, China JEL Codes: M13; D85; L14; L25; P27 
As China's economy is growing rapidly, the domestic private sector is emerging from the shadows and playing a prominent role in the country's economic development. Owing to the historical, institutional and cultural factors, the private sector in China exhibits a high degree of informality. Many enterprises possess vague property rights, ownership structure, corporate governance mechanisms, and financial records. This gives private entrepreneurs great flexibility to respond to an uncertain world composed of rapidly changing market conditions and unstable government regulations. This environment however also constitutes a great challenge to entrepreneurs to put their businesses on a firmer footing. Entrepreneurs find that an effective way of managing hostile environments in transition economies is doing business through personal networks of relationships because network ties provide resources and information, and help to find clients, suppliers, and investors, who are socially bound (Peng 2001). In this article, I examine the way in which Internet entrepreneurs in China (re) combine their personal networks and human capital to create viable e-businesses (Amit \& Zott 2001). Specifically, I examine the interaction effects of entrepreneurs' social networks and human capital on the survival likelihood of Internet ventures and explore the changes in entrepreneurs' networks over time.

There are two mainstream arguments about what types of social networks in terms of structure are beneficial to individuals, groups and organizations. On the one hand, coherent and dense networks enable actors to achieve their goals effectively because of cooperative behavior of members, high trust embedded in relationships and informal social mechanisms that control opportunistic behaviors (Coleman 1988). On the other hand, sparse and non-redundant networks facilitate actors' access to new information, opportunities and resources promoting success of instrumental actions (Burt 1992).

The instrumental value of networks however is contingent upon institutional and social context, and behaviors of individuals and organizations (Galaskiewicz \& Zaheer 1999). For example, Burt (1997) argued that structural holes, i.e., disconnections between nonredundant contacts in a network, are especially valuable to managers with few peers. Podolny \& Baron (1997) reported that structural holes in individual networks had significant positive and negative effects on career advancement depending on the network content. At organizational level, Gulati \& Higgins (2003) established that new firms' ties to prominent venture capital firms are particularly beneficial to IPO success during cold markets, while ties to prominent investment banks are particularly beneficial to IPO success during hot markets. Likewise, Batjargal \& Liu 
(2004) found that effects of dyadic and triadic ties of entrepreneurs and venture capitalists on investment decisions made by venture capitalists were dependent on the human capital of entrepreneurs and technical qualities of venture projects. There is however a considerable gap in the literature on under what conditions structural properties of entrepreneurs' networks affect venture performance. A purpose of this study is to examine the contingent value of structural holes in an entrepreneur's network, i.e., when, where and how much structural holes are valuable, to the survival likelihood of startups by focusing on the interaction between structural holes and founders' industry, startup and international experience.

Networks contain inherent tensions between status quo and changes in terms of structure, composition and resources (Burt 2000, Gulati et al. 2001). Yet little is known about how personal networks evolve over time and how dynamics of networks influence results of purposive actions of actors. In this study, I examine how entrepreneurs' network structure evolves over time, and the way in which changes in social skills of entrepreneurs influence performance of young firms.

The country and industry context is the Internet industry in China. The Chinese Internet industry is an emergent sector, and therefore, there are a few commonly accepted rules, norms and "taken for granteds" to govern relationships (Nee 1992). This results in greater institutional and social uncertainties where personal relationships are important resources to get things done (Xin \& Pearce 1996). The contingent value of networks therefore might be more pervasive in this industry and country context than in relatively mature industries and market economies (Galaskiewicz \& Zaheer 1999). Furthermore, study of Internet entrepreneurship in general and Internet ventures in emerging markets in particular is a new research field (Amit \& Zott 2001). I think that this study is one of the first studies of the Chinese information and Internet industry that generated US\$99.2 billion in revenues in 2001 (Business Weekly 2002). Finally, the Chinese cultural and social milieu, which is regarded as relationship intense (Boisot \& Child 1996), makes social networks dynamic and important for performance. These reasons justify the choice of the industry and country contexts of this study.

The article is structured as follows. In the next section, I examine the Chinese version of networks - guanxi, and the Internet industry in China. In the following section, I propose hypotheses on venture survival and network dynamics. The methods section describes the sample and data collection, the variables and measurements, and the construct validation 
procedures. In the results and discussion sections, I report the findings and interpret them in light of network theory. In the conclusion, I discuss the implications, the contributions and the limitations of this study.

\section{CONTEXT}

\section{Social Networks in China: Guanxi}

The Chinese version of social networks is guanxi (connections) (King 1991). Guanxi is defined as a special relationship due to the existence of particularistic ties (Tsui et al. 2000). A set of networking strategies and tactics in China is called guanxixue - art of networking (Yang 1994). Guanxixue is composed of numerous relationship building techniques and maintenance rituals (Gold et al. 2002). La guanxi (pull relationship) is a credo that describes a set of contact identification, approach and recruitment techniques. Empirical research on guanxi has produced both positive and negative effects of guanxi on outcome variables. Guanxi capital (Bian 2001) promotes interpersonal trust (Farh et al. 1998) and enhances firm performance (Park \& Luo 2001; Peng \& Luo 2000). However, guanxi relationships have negative effects on dependent variables under certain circumstances (Chen et al. 2004; Tsui et al. 2002). The contingent effects of guanxi, and dynamics of guanxi remain largely unexplored in guanxi research.

\section{The Internet Industry in China}

The year 1994 is regarded as the start of the Internet connection in China (CNNIC 2002a). The Internet industries cover Internet content providers, portals, Internet service providers, manufacturers of networking and telecommunication equipment, e-commerce firms, online business of non-Internet firms, software firms, and other related activities such as IT consulting and e-education. There were 80 million Internet users in China at the end of 2003. The number of Internet protocol address in China reached 23 thousand. Domain names registered under .CN totaled 126 thousand, while web sites reached 293 thousand. According to WebSideStory Inc, China accounted for 6.63 percent of global Internet traffic during July 2002 becoming world's second largest web market after the United States.

In 2001, the information industry growth rate reached 20 percent. The Nasdaq listed portals, i.e., Sina.com, Sohu.com, and Netease.com, that dominate the Internet content market, are profitable due to the burgeoning market of SMS (short message services). China's ecommerce volume in 2000 totaled \$9.33 billion, 99 percent of which was B2B transactions. There were 677 domestic B2C virtual stores and 370 B2B commercial websites (Chinaonline 
2001). In terms of region, Beijing leads the country. Some thirty-one percent of dot cn domain names and 21 percent of websites were registered in Beijing (CNNIC 2002b). Although the Internet industry in China is developing rapidly, there are numerous legal, regulatory and investment problems. The Chinese government blocks as much as 10 percent of the Internet, covering sites dealing with Taiwan, Tibet and dissidents along with news media, pornography and religious sites (CNN.com 2002). The bulk of financial investments into Internet industry is concentrated in large cities, furthering the "digital divide" between Chinese provinces.

\section{HYPOTHESES}

\section{Firm Survival}

The social network theory postulates that networks' structural holes present opportunities, which may be transformed into profit by financial and human capital of actors (Burt 1992). Outcomes of purposive actions of actors are dependent on the combinations of various types of capital players bring into market (Bourdieu 1986; Coleman 1988). Structural hole is, Burt (1992: 18) defined, "a relationship of nonredundancy between two contacts. The hole is a buffer, like an insulator in an electric circuit. As a result of the hole between them, the two contacts provide network benefits that are in some degree additive rather than overlapping”. A structural hole is a disconnection or extremely weak relationship between two contacts. Structural holes are universal phenomena observable in any human networks including American, Chinese and French managerial networks (Burt et al. 2000; Tsui et al. 2002). Those entrepreneurs whose personal networks are rich in structural holes are likely to do well because of benefits sparse networks generate. Structural holes may lead to greater entrepreneurial opportunities in the form of new sales and supplier contracts, access to advertising channels, financial capital and important decisions, and participation in alliances and joint projects. A crucial benefit entrepreneurs obtain from sparse networks is timely access to nonredundant information and referral sources (Burt 1992). Entrepreneurs whose network position is central among disconnected clusters are likely to control information flows and in this way, they are likely to manufacture greater credit slips, which enhance their exchange power (Coleman 1988). Structural holes generate more diverse and creative ideas since people who live in the intersection of social worlds tend to have valuable ideas (Burt 2004). Structural holes promote greater structural autonomies that enable entrepreneurs to act upon new opportunities and neutralize harmful effects of costly concessions to strong ties. 
The way in which entrepreneurs exploit new opportunities spotted in structural holes is dependent on the motivation, ability and experience of entrepreneurs (Burt 1992). In this way, human capital, i.e., education and skills (Becker 1975), transforms opportunities into tangible benefits. I propose that entrepreneurial (startup) experience will enhance benefits of nonredundant networks for Chinese entrepreneurs. Sparse networks are effective when entrepreneurs have tacit knowledge of the process of venture creation and first-hand experience of product development because experienced entrepreneurs are able to entangle venture-specific opportunities and information from the sea of information and opportunity flows in networks (Bruderl et al. 1992). Habitual entrepreneurs have sharpened alertness to brokerage tensions and profit from tertius gaudens - "the third who benefits" effectively (Burt 1992). Confidence gained from previous startups motivates founders to seek out decisively or even create deliberately inefficiencies in networks and manipulate skillfully between sides. Field interviews support this logic. Michael Chui, the CEO of "Beijing Hi-world software technology", said in an interview:

When we started the construction company, we realized that we need people who know well not only construction electronics (lighting or elevators) but also IT and network systems including software to manage large building's electronics, security system and service infrastructure. Among senior managers, my profession was closest to match the need and I started to work on this. Eventually, I realized that there is no software company in China that writes software for tall buildings (office, hotels and convention centers). Construction firms do not engage in software development, and software programmers overlook this niche of the market. I started this venture to fill this gap. To date, I am very satisfied with how things are going” (Author's interview, July 2002, Beijing).

\section{Hypothesis 1: The number of structural holes in the entrepreneur's network is associated positively with firm survival when the entrepreneur has startup experience.}

The next hypothesis is on why and how Internet industry experience strengthens impacts of structural holes on firm performance. Experienced entrepreneurs whose networks are rich in structural holes are likely to detect signals of technology progress earlier. Industry specific knowledge would enable entrepreneurs to identify correctly their firms' positions in the competitive network of the industry and position their firms in such a way that their strengths match opportunities and negative implications of threats and weaknesses are neutralized. Since Internet industry is a new industry, there are many gaps and vacuums in the value chain (Amit \& Zott 2001). Founders who are positioned in between disconnected network cliques would be the ones who get information first and perceive lucrative opportunities in time (Burt 1992). Working 
in the Internet industry enables entrepreneurs to follow how demands for products and services evolve, and customize their products accordingly to increase revenue. The regulatory framework of the industry is in flux in China and therefore, well-connected CEOs will be able to respond competitively to new policies and rules. This reasoning is consistent with an expert's observation. Professor Wang of Peking University concludes that combination of industry knowledge and guanxi networks helped high tech entrepreneurs to succeed:

Most entrepreneurs in the Zhongguancun district have been working before in R\&D institutes of the Chinese Academy of Sciences and universities. They possess excellent technological knowledge and use them in creative ways. Furthermore, everybody seems to be connected to everyone else in the district because often they are graduates of Peking University and Tsinghua University. This guanxi "infrastructure" seems to facilitate their success (Author's Interview, September 2002, Beijing).

Hypothesis 2: The number of structural holes in the entrepreneur's network is associated positively with firm survival when the entrepreneur has Internet industry experience.

A unique sub-population of the new entrepreneurial class in China is entrepreneurs who returned to China after obtaining education and work experience in Western developed countries. For example, 9000 returned specialists founded their businesses or teamed up with others to create high tech ventures in the Zhongguancun Science Park in Beijing within first three years of operation of the park (Liu 2002). I hypothesize that Chinese entrepreneurs who studied and worked in the West (North America and Western Europe) are likely to benefit more from nonredundant networks. Western-trained entrepreneurs possess superior technology, management and market know-how, personal networks in the West, and language skills and cultural awareness (Wattanavitukul 2002). They are knowledgeable of diverse sources of information and effective ways of how and when to collect reliable information. Language skills enable returnees to keep track of the latest Internet technology and industry trends in the West, and capitalize on brokerage opportunities since China is following the West in the information industry. Returned Internet entrepreneurs would benefit from being late-movers because they learn what e-business models are effective in the West, and what mistakes they must avoid. Transnational entrepreneurs whose networks contain many disconnected ties in different countries, for example, United States and China, are likely to profit more from brokerage roles and opportunities of joint ventures, alliances, mergers and acquisitions, and venture capital investments. Returnees are placed in the intersections of learning and professional networks in the West, current business networks in China, and ties with schoolmates and colleagues prior 
Western experience in China. This may expose them to diverse ideas and opportunities that might be exploited. Furthermore, education and socialization in more individualistic cultures of the West may make these executives less hesitant to profit from brokerages in networks. Interviews with returned specialists support these assumptions. Henry Lee, the CEO of Readchina.com - an Internet content provider (ICP), explained:

China is a nation that has unique cultural traditions. I appreciated this during my study and work in Canada for a decade. When you live in the West, you learn to look at things in China from different perspectives. You recognize strengths and weaknesses of everything Chinese government, economy, education and culture. You learn to combine the best of the two systems. I believe this is an extremely important advantage (Author's Interview, June 2001, Beijing).

Hypothesis 3: The number of structural holes in the entrepreneur's network is associated positively with firm survival when the entrepreneur has Western experience.

\section{Network Dynamics}

Despite its theoretical and practical importance, little is known about how networks of individuals change over time. Network methodologists theorized that dynamics of network structure are a function of individual needs and choices because actors choose to form or delete relationships (e.g., friendship ties) and rational behavior of players who structure their networks to maximize their power (Willer \& Willer 2000; Zeggelink 1994). For example, Burt (2000) found that relationship decay defined as the tendency for relationships to weaken and disappear is a function of tie age (the older the relationship the lower the decay rate) and node age (the older the node, i.e., banker, the lower the decay rate). I propose that the way in which guanxi networks of entrepreneurs evolve over time is a function of networking skills of entrepreneurs. Networking skills are a set of strategies, tactics and rituals of contact recruitment, relationship maintenance and resource mobilization. A skillful network builder is a motivated actor (Kadushin 2002) who is knowledgeable of existing methods and routines of network expansion and restructuring (Yang 1994). An effective network builder clarifies first what kind of member in terms of power, wealth, network position, reputation, expertise and personality is required to satisfy her business needs. This is followed by systematic search for an appropriate contact. Once the target person is found, a set of approach techniques such as using a trusted intermediary, cold 
calls, or cruising around the "right" places, will be deployed. The President of "Chuangshi Tengfei", an Internet service provider (ISP), concluded:

Although the Chinese are ambiguous towards guanxi practice, guanxixue is a part of the traditional Chinese culture. Some people say "no guanxi no job", or "no guanxi no success"... It is extremely difficult to refuse to your friends' or colleagues' requests since all involved lose their face. The Chinese are, in my view, immersed to establish relationships with useful people” (Author's interview, June 2001, Beijing).

Entrepreneurs who are skilled in guanxixue are likely to build networks rich in structural holes because they are keenly aware of brokerage opportunities they present. A significant part of networking activities therefore is devoted to recruitment of ties from different sectors (e.g., officialdom versus private sector) and disconnected clusters.

\section{Hypothesis 4: Networking skills of the entrepreneur are associated positively with the increase of structural holes in the network over time.}

\section{Firm Legitimacy}

The more the entrepreneurs practice guanxi the more they learn the culture and nuances of networking. Improvements in networking skills lead to greater ability to locate desirable partners, choose effective recruitment techniques, and reduce direct and indirect costs of tie establishment, cultivation and maintenance. In this way, improved social and communication skills are likely to generate greater "social returns". Entrepreneurs learn new networking techniques, e.g., intense online communications, and come up with creative combinations of existing methods with new twists to improve their social status. Progress in social skills will be reflected in improved abilities to categorize ties accurately, and get rid off costly contacts gradually. Entrepreneurs analyze network structures and composition, and design and implement suitable strategies for network restructuring and membership turnover. In addition, entrepreneurs are likely to strike a balance between strong and weak ties since both provide different benefits.

It is assumed that improved social skills of entrepreneurs would be associated with increased firm legitimacy defined as a generalized perception that the actions of firms and entrepreneurs are desirable, proper and appropriate (Suchman 1995). Superior social skills of executives help their firms to gain central network positions that are prestigious and approved, and enable them to neutralize negative perceptions of brokers who take advantage of others. Negotiating the external environment of the firm smoothly creates positive impressions of the firm's activities. This is reflected in the increased numbers of outside investors besides venture 
capitalists. In addition to delivering resources and technology, institutional investors enhance legitimacy and status of new firms (Eisenhardt \& Schoonhoven 1996, Stuart et al, 1999).

Hypothesis 5: Improvement in networking skills of the entrepreneur is positively associated with increase in the number of investors.

\section{METHODS}

\section{Sample and Data}

The data is composed of structured telephone interviews with 94 Internet entrepreneurs in July-August 2001, and follow-up interviews with 52 original respondents in August-September 2002. All interviews were conducted in Beijing. In 2001, my research assistants and I created a list of 410 Internet related firms (Internet service providers, Internet content providers, ecommerce, network technology, software) based in Beijing. In all, we contacted 120 CEOs selecting every-third on the list of 382 firms whose contact details were identified, and 98 agreed to be interviewed. The positive response rate is 81 percent. After one-year interval (Burt 2000), we re-interviewed 52 respondents. Some thirteen respondents declined our request, and 29 firms were unreachable suggesting that these firms are no longer functional. We verified non-existence of these firms by employing three procedures. First, we tried to contact them through phone, fax, and email. Second, we checked their websites and found that most do not exist or inactive. Finally, we looked at China yellow pages 2002 and did not find these firms except three. For validity reasons, I compared the sample of 52 re-interviewed entrepreneurs with 13 refused respondents, and ANOVA results on firm age, firm size, and number of structural holes in 2001 did not suggest any significant differences between two samples. The questionnaires were designed in English. The English version was translated into Chinese by a Chinese professor. Another Chinese professor back translated the Chinese version. Teams of three research assistants based at Peking University conducted phone interviews in 2001 and 2002. Each interview lasted approximately in 40 minutes.

\section{Measures}

Independents. Structural holes 2001 is measured as the number of structural holes in the network of each respondent in 2001. The questions that capture structural holes are presented in the Appendix. Five questions on professional contacts, informal contacts, discussion contacts and spouse were asked to generate names. Finally, respondents were asked to describe the connection between each pair of contacts as especially close, distant, or something intermediate. The number 
of distant relationships in a network is the number of structural holes. Structural holes 2002 is the difference between the number of structural holes in 2001 and 2002. Internet experience is measured as years of working in the Internet industry (Schoonhoven et al. 1990). Startup experience is a binary variable of one if the entrepreneur is experienced, and zero otherwise (Bruderl et al. 1992; Schoonhoven et al. 1990; Shane \& Stuart 2002). Western experience is measured in years of working and study in Western developed countries (North America and Western Europe). Networking skills 2001 is measured by a scale that is comprised of three questions: "I am good at the art of networking"; "My friends think of me as someone who is good at the art of networking"; "I always make efforts to expand and enrich my networks". Distribution values of each question were five-point Likert scale items ranging from strongly agree (5) to strongly disagree (1). I computed the scale by adding up the values in each item and dividing them by three. Networking skills 2002 is the difference between the scales in networking skills in 2001 and 2002.

Dependents. Firm survival is a binary variable of one if the firm survived, and zero otherwise. The otherwise category includes all unreachable firms in 2002. Thirteen respondents who refused to be re-interviewed were excluded from the analysis. Investors 2002 measure firm legitimacy (Eisenhardt \& Schoonhoven 1996). The question "how many firms (excluding venture capital firms) invested in your firm" captures the number of investors. Investors 2002 is the difference between the number of investors in 2001 and 2002.

Controls. Firm age is measured as years from the date of registration. The number of full-time employees in 2001 measures firm size. Venture capital indicates the sum of private equity raised before 2001 survey in thousand \$. Government officials are regarded as important contacts in China (Peng \& Luo 2000) and therefore, I included officials 2001 that measures the percentage of government officials in a network. Young firm alliances are important predictors of their performance (Baum et al. 2000; Stuart et al. 1999). Therefore, I included a control variable project partners 2001 that captures the number of state owned R\&D institutions with whom the firm has joint product development projects. Project partners 2002 is the difference between the number of partner institutions in 2001 and 2002. Finally, I control for various subsectors within the Internet industry because previous research showed that external factors and market stage influence new venture survival and growth (Eisenhardt \& Schoonhoven 1990). Firms were classified as Internet service and content provider, e-commerce firms, software firms 
and other Internet related (networking equipment, distributors and others) as the main business by revenue.

Construct validity. Measurements for structural holes are externally valid since the method of name generation has been proved as valid (Burt 1992; 2004; Burt et al. 2000). I counted the number of contacts who were named again in 2002 and found that 82 percent of contacts from 2001 were named again in 2002 on average. This indicates an acceptable compositional reliability (Marsden 1993) and is consistent with findings of previous research (Podolny \& Baron 1997). Thus, network measurements are internally and externally valid.

The reliability coefficient (Cronbach alpha) for networking skills 2001 is 0.81. I conducted a confirmatory factor analysis of the measurement model associated with Likert scale items to assess how well the interview questions load onto the constructs. I found that the comparative fit index is 0.84 , the incremental fit index is 0.92 , and the root mean squared error of approximation is 0.075 . The findings suggest that the measurement is valid and reliable. Since the questions on networking skills 2001 are perceptual items, I did validate these data by calling up 20 randomly chosen friends of respondents. In all, 61 respondents provided phone numbers of their friends in 2001. We contacted 20 friends selecting every third on the list. We asked the question "How do you assess networking skills of your friend (the entrepreneur)", and found that answers of 18 (90\%) friends were consistent with answers of respondents. Therefore, this measurement is externally valid.

Some twelve entrepreneurs provided phone numbers of outside investors in 2001, and we confirmed investors' equity ownership by calling up every second investor (6) on the list. The findings were confirmatory. Some seven institutes who have joint $R \& D$ and design projects were contacted by phone and asked to confirm the entrepreneurs' claim in 2001. All organizations except one institute gave positive answers. Thus, these measurements are valid externally.

In order to collect additional financial performance data, we approached the Taxation Department of the Haidian district government in north Beijing where most of the surveyed firms were registered. We created a list of 15 randomly chosen firms from 52 re-interviewed, and asked the taxation department to provide financial information on these firms. A senior officer from the department declined our request, but confirmed that all 15 firms were functioning and paying taxes by the end of September 2002. Although we do not have hard accounting information, this confirmation indicates the validity and reliability of firm performance. A 
research assistant, who was not a member of the interview teams, conducted data validation interviews and phone calls. This study is a cross-level study in terms of unit of analysis. Independent and some dependent variables are measured at individual (CEO) level but some dependent variables and control variables are measured at organization level. Such research strategies are acceptable as long as measurements and constructs are valid internally and externally (Rousseau, 1985).

\section{RESULTS}

\section{Descriptive Statistics}

Table 1 suggests that the firms in the sample become less diversified over 1 year period. Most firms except ISPs and equipment distributors decreased their scope. This is explained by the crisis in the Internet industry in 2000, which forced players to concentrate financial and human resources on their core businesses.

Table 2 presents descriptive statistics and Pearson's correlations. I present here the data on 52 re-interviewed entrepreneurs in 2002. The mean age of surveyed startups is 2.67 years. The number of full-time employees was 41 (S. D = 61.76) in 2001 indicating that most firms are small. The mean volume of venture capital raised is $\$ 192$ thousand (S.D = 455). The mean number of structural holes in 2001 was 6.76, and officials of various ranks comprised 11 percent of network members in 2001. Changes in networking skills, structural holes, institutional investors, and project partners were positive in 2002.

Insert Table 1 and 2 about here

\section{Firm Survival}

In Table 3, I present the results of logistic regression analysis predicting firm survival in 2002. Model 1 is the base model that examines effects of all independent and control variables on venture survival likelihood. The model is significant (Chi-square 25.16). The model reveals that project partners 2001 (Baum et al. 2000; Lee et al. 2001, Stuart et al. 1999), startup experience (Bruderl et al. 1992; Gimeno et al. 1997) and Western experience have significant positive effects on firm survival. The model indicates that software firms were less likely to survive.

\section{Insert Table 3 about here}

Models 2, 3, 4 and 5 explore effects of interactions of structural holes with startup experience, Internet experience and Western experience on firm survival likelihood. Model 2 
reports insignificant negative effects of interactions of structural holes and startup experience, and positive main effects of structural holes and startup experience on venture survival. Model 2 is significant (Chi-square 17.1). The main positive effect of structural holes is consistent with findings of previous research (Burt 1992, 2000; Podolny \& Baron 1997). Hypothesis 1 that predicted positive interaction effects of structural holes and startup experience on firm survival is not supported. Model 3 illustrates that interactions of structural holes and Internet experience have no effects on firm survival. The model is significant (Chi-square 18.27). Hypothesis 2 that proposed positive interaction effects of structural holes and Internet industry experience on firm survival is not supported. Model 4 reveals that interaction effects of structural holes and Western experience on firm survival are significant and positive. The model is significant (Chi-square 26.48). The impact of structural holes on firm survival is contingent upon Western experience of founders. Hypothesis 3 that predicted positive interaction effects of structural holes and Western experience on firm performance is supported. Model 5 illustrates effects of all variables on venture survival. The model is significant (Chi-square 39.79). The model reveals positive main effects of project partners 2001, startup experience and Western experience on firm performance. The model reveals positive interaction effects of structural holes and Western experience, and negative interaction effects of structural holes and startup experience on venture survival.

\section{Network Dynamics and Firm Legitimacy}

Table 4 demonstrates the results of linear regression analysis predicting changes in structural holes, and investors. Model 1 reveals that networking skills 2001 are associated positively with the increase of structural holes in founders' networks over time. The model is significant $(\mathrm{F}=3.1)$. Hypothesis 4 that predicted positive relationships between networking skills and increase in structural holes is supported. Model 2 suggests that improvement in networking skills is associated positively with the net increase in the number of new investors in 2002. The model is not significant. Hypothesis 5 that proposed positive relationships between improvement in networking skills and net increase in the number of investors is supported.

Insert Table 4 about here

\section{DISCUSSION}

The findings reveal mixed results for proposed hypotheses. Entrepreneurial experience and structural holes are two variables that do not "interact" with each other. Contrary to my prediction, combination of startup experience and structural holes is harmful for venture 
performance. In contrast to novice entrepreneurs, habitual entrepreneurs have established reputations within the local entrepreneurial community, i.e., Zhongguancun district, and therefore, they deliberately avoid exploiting opportunities spotted in bridge relationships because brokers in general are perceived as manipulators in China. As entrepreneurs act to create new ventures, stories about their behaviors are told and retold (Lounsbury \& Glynn 2001). Negative stories about entrepreneurs may harm their reputation, legitimacy and performance. Therefore, habitual entrepreneurs may be hesitant to act as intermediaries between unconnected ties. Correlations in Table 2 reveal that startup experience and Western experience are correlated negatively although the coefficient is insignificant. This may suggest that those entrepreneurs who have startup experience have less Western experience. Consequently, they have been engaged in local entrepreneurial activities longer. The inverse indicator of a sparse network is a dense network where alters are connected (Burt 1992; Podolny \& Baron 1997). It is suggested that dense and cohesive networks, i.e., fewer structural holes, are effective when entrepreneurs have startup experience. Cohesive networks are conducive to firm survival because of high trust, cooperative norms and informal sanctions for deviant behaviors. The finding suggests that structural holes have negative contingent effects on firm survival. This is consistent with findings of Ahuja (2000) and Podolny \& Baron (1997) who found negative main effects of structural holes on outcome variables in the Western context, and Tsui et al (2002) who found negative main effects of structural holes in the Chinese context. The evidence that dense networks may be more useful for serial entrepreneurs is in support of the closure type of social capital elaborated by Coleman (1988).

Internet industry experience is not beneficial to exploitation of brokerage opportunities. Working in the Internet industry and creation of new e-businesses does not enhance entrepreneurs' abilities to profit from arbitrage opportunities in disconnected network clusters.

Western trained entrepreneurs do better due to their superior skills in turning opportunities spotted in structural holes into viable products and services. They are psychologically comfortable to profit from their network positions that link various cliques. Western experienced entrepreneurs sell greater volumes at higher prices and buy more at lower costs, because their customers and suppliers are disconnected players.

The previous research found positive contingent effects of networks on outcome variables (Burt 1997; Galaskiewicz \& Zaheer 1999). This study revealed both positive and 
negative contingent effects of structural holes on firm survival, depending on the type of human capital, e.g., startup and Western experience.

Internet ventures allied with government $R \& D$ institutes were more likely to survive. Alliances with R\&D institutions facilitate access to information, financial resources, new product ideas, technologies, government contracts, subsidies, exclusive licenses and permissions, government sponsored promotions of product brand names through exhibitions, competitions and quality certificates, and government controlled advertising, marketing and distribution channels.

The Chinese entrepreneurs learn techniques and rituals of guanxixue and systematically deploy them for effective network building (Yang 1994). Relationship building and maintenance is fruitful to the extent that they recruit and retain nonredundant contacts from resource-rich clusters. Those entrepreneurs who know well nuances of brokerage go after new contacts consciously and recruit them skillfully. Theoretically, the finding indicates that individual network evolution is a function of networking strategy of players other things being equal (Willer \& Willer 2000; Zeggelink 1994).

Improved networking skills help entrepreneurs to find prestigious institutional investors, e.g., large corporations and financial institutions, and approach them in the "right" way at the "right" time. Well-oiled guanxi techniques convince potential investors in trustworthiness, predictable post-investment behavior, and good intentions of the entrepreneurial team (Batjargal \& Liu 2004). Improved abilities to deploy guanxi methods in creative ways help Chinese entrepreneurs to make guanxi deals effectively. New investors promote positive perceptions of Internet ventures, assist these firms to obtain higher status and neutralize liabilities of newness. Thus, improved social skills lead to greater institutional and cognitive legitimacy of new ventures.

\section{CONCLUSION}

This study found that effects of structural holes on venture performance are contingent on the type of experience entrepreneurs have. Entrepreneurs who have different experience, i.e., startup versus Western, are effective players in different networks. Cohesive networks are especially beneficial to those who started businesses before and who are embedded more in local networks. On the contrary, sparse networks are especially beneficial to those entrepreneurs who 
studied and worked in the West. "Local" and "Western" entrepreneurs capitalize on different benefits each type of networks offers. Local entrepreneurs benefit from high trust, cooperative behavior and informal norms in tight networks. Western entrepreneurs benefit from information, opportunity and control benefits in sparse networks that connect different countries, regions and clusters. This study indicates that the network closure advanced by Coleman (1988) and the network brokerage advocated by Burt (1992) are not mutually exclusive, and both can be effective depending on the context.

Future research should examine whether contingent effects of structural holes are universal across cultures or culture-specific. Another dimension of future research is to examine how effects of other network parameters, e.g., network content and relational trust, on performance are influenced by contextual and behavioral factors. The study implies that entrepreneurs should deploy various types of capital, e.g., social and human capital, in recombined manners for entrepreneurial success (Schumpeter 1961). A possible question that could be studied further is how inherent tensions of inertia and change in networks interact and evolve over time. It implies that competitive players are recommended to learn and re-learn networking techniques and routines to shape and restructure their networks constantly to generate greater opportunities. An interesting issue that could be explored is that how and why perceived improvements in networking skills influence other outcome variables, for example, financial and innovation performance of firms. Entrepreneurs are advised to be socially creative and alert to new networking methods that may broaden their opportunity horizons.

This study contributes to social network theory in the sense that indirect effects of structural holes on outcome variables can be both positive and negative. Individuals can shape and restructure their networks if they are strategic in their networking behaviors. This article contributes to the literature on e-business and entrepreneurship by empirically proving that Internet entrepreneurs do create values by combining their social and human capital.

Several limitations of the study should be discussed. Some measurements are context specific, e.g., Western experience. This may impose limits on generalizability of the findings to other social and cultural contexts. The industry context of the study is the Internet industry in China, which is less than 10 years old. The institutional, regulatory and market immaturity may have affected the results although I assume that all entrepreneurs are exposed to the similar country, industry and cultural contexts to the same extent. The sample size is small, and standard 
deviations for some variables are rather high. Lastly, some of the findings are rather tentative, and therefore, one should be cautious of over generalization of the results. 


\section{REFERENCES}

Ahuja, G. (2000) 'Collaboration Networks, Structural Holes, and Innovation: A Longitudinal Study’, Administrative Science Quarterly 45: 425-455.

Amit, R. and Zott, C. (2001) 'Value Creation in E-business', Strategic Management Journal 22: 493-520.

Batjargal, B. and Liu, M. (2004) 'Entrepreneurs' Access to Private Equity in China: The Role of Social Capital’, Organization Science 15 (2): 159-172.

Baum, J. Calabrese, T. and Silverman, B. (2000) 'Don't Go it Alone: Alliance Network Composition and Startups' Performance in Canadian Biotechnology'. Strategic Management Journal 21: 267-294.

Becker, G. (1975) Human Capital, New York: National Bureau of Economic Research.

Bian, Y. (2001) 'Guanxi Capital and Social Eating in Chinese Cities', In N. Lin, K. Cook, and R. Burt (eds.) Social Capital, Theory and Research, Aldine De Gruyter: New York. pp: 275-295.

Boisot, M. and Child, J. (1996) 'From Fiefs to Clans and Network Capitalism: Explaining China’s Economic Order’. Administrative Science Quarterly 41: 600-628.

Bourdieu, P. (1986) 'The forms of Capital', In J. Richardson, (Ed.) Handbook of Theory and Research for the Sociology of Education, 241-258. Greenwood: New York.

Bruderl, J. Preisendorfer, P. and Ziegler, P. (1992) 'Survival Chances of Newly Founded Business Organizations, American Sociological Review 57: 227-242.

Burt, R. (1992) Structural Holes, The Social Structure of Competition, Harvard University Press: Cambridge, MA.

Burt, R. (1997) 'The Contingent Value of Social Capital', Administrative Science Quarterly 42: 339-365.

Burt, R. (2000) 'Decay Functions’, Social Networks 22: 1-28.

Burt, R. (2004) ‘Structural Holes and Good Ideas’, American Journal of Sociology, in press.

Burt, R. Hogarth, R. and Michaud, C. (2000) The Social Capital of French and American Managers', Organization Science 11: 123-147.

Business Weekly, (2002) Beijing, 5-11 February: 13.

Chen, C. Chen, Y. and Xin, K. (2004) 'Guanxi Practices and Trust in Management: A Procedural Justice Perspective’, Organization Science 15 (2): 200-209. 
Chinaonline (2001) 'B2B Transactions Dominated China's E-commerce in 2000, 21 February, Beijing.

CNN.com, (2002) 'China blocking 10 percent of Internet', December 3.

CNNIC (China Internet Network Information Center), (2002a) The Internet in China, Beijing.

CNNIC (2002b), The10th Statistical Survey Report on the Development of the Internet in China, Beijing.

Coleman, J. (1988) 'Social Capital in the Creation of Human Capital', American Journal of Sociology’, 94 (Supplement): 95-120.

Eisenhardt, K. and Schoonhoven, C. (1996) 'Resource-based View of Strategic Alliance Formation: Strategic and Social Effects in Entrepreneurial Firms', Organization Science, 7 (2): 136-150.

Farh, L. Tsui, A. Xin, K. and Cheng, B. (1998) 'The Influence of Relational Demography and Guanxi: The Chinese Case’, Organization Science 9 (4): 471-488.

Galaskiewicz, J. and A. Zaheer, (1999) 'Networks of Competitive Advantage', Research in the Sociology of Organizations 16: 237-261.

Gimeno, J. Folta, T. Cooper, A. and Woo, C. (1997) 'Survival of the Fittest? Entrepreneurial Human Capital and the Persistence of Underperforming Firms, Administrative Science Quarterly 42: 750-783.

Gold, T. Guthrie, D. and Wank, D. (2002) 'An Introduction to the Study of Guanxi', In T. Gold, Guthrie, D, and Wank, D. (Eds.) Social Connections in China: Institutions, Culture and Changing Nature of Guanxi Cambridge University Press: Cambridge, pp. 3-12.

Gulati, R. Nohria, N. and A. Zaheer (2001) 'Strategic networks', Strategic Management Journal 21: 203-215.

Gulati, R. and M. Higgins (2003) 'Which Ties Matter When? The Contingent Effects of Interorganizational Relationships on IPO Success’, Strategic Management Journal 24: 127-144.

Kadushin, C. (2002) 'The Motivational Foundation of Social Networks', Social Networks, 24: 77-91.

King, A. (1991) 'Kuan-hsi and Network Building: A Sociological Interpretation’, Daedalus, 120 (2): 63-84.

Lee, C., Lee, K. and J. Pennings (2001) 'Internal Capabilities, External Networks, and Performance: A Study of Technology-based Ventures', Strategic Management Journal 22: 615640. 
Liu, Z. (2002) 'Zhongguancun, the Most Dynamic Regional Technological Innovation Base, Manuscript, Zhongguancun Science Park, Beijing.

Lounsbury, M. and Glynn, M. (2001) 'Cultural Entrepreneurship: Stories, Legitimacy, and the Acquisition of Resources’, Strategic Management Journal, 22: 545-564.

Marsden, P. (1993) 'The Reliability of Network Density and Composition Measures', Social Networks, 15: 399-421.

Nee, V. (1992) 'Organizational Dynamics of Market Transition: Hybrid Forms, Property Rights, and Mixed Economy in China’, Administrative Science Quarterly 37: 1-27.

Park, S. and Luo, Y. (2001) 'Guanxi and Organizational Dynamics: Organizational Networking in Chinese Firms’, Strategic Management Journal, 22: 455-477.

Peng, M. (2001) 'How Entrepreneurs Create wealth in Transition Economies', Academy of Management Executive 15 (1): 95-110.

Peng, M. and Luo, Y. (2000) 'Managerial Ties and Firm Performance in a Transition Economy: The Nature of a Micro-macro Link’, Academy of Management Journal 43 (3): 486-501.

Podolny, J. and Baron, B. (1997) 'Resources and Relationships: Social Networks and Mobility in the Work Place’, American Sociological Review 62: 673-693.

Rousseau, D. (1985) 'Issues of Level in Organizational Research: Multi-level and Cross-Level Perspectives’, Research in Organizational Behavior, 7: 1-37.

Schoonhoven, C, Eisenhardt, K. and Lyman, K. (1990) 'Speeding Products to Market: Waiting Time to First Product Introduction in New Firms’, Administrative Science Quarterly 35: 177207.

Schumpeter, J. (1961) The Theory of Economic Development, Harvard University Press: Cambridge, MA.

Shane, S. and Stuart, T. (2002) 'Organizational Endowments and the Performance of University Startups’, Management Science 48 (1): 154-170.

Stuart, T. Hoang, H. and Hybels. R. (1999) 'Interorganizational Endorsement and the Performance of Entrepreneurial Ventures’, Administrative Science Quarterly, 44: 315-349.

Suchman, M. (1995) 'Managing Legitimacy: Strategic and Institutional Approaches', Academy of Management Review, 20: 571-610. 
Tsui, A, L. Farh, and Xin. K. (2000) 'Guanxi in the Chinese Context', In J.T. Li, A. Tsui and E. Weldon, (eds.), Management and Organization in the Chinese Context, Macmillan: London, pp. 225-244.

Tsui, A. L. Farh and Xin, K. (2002) 'Social Capital or Negative Capital: Particularistic Ties in Chinese Managerial Networks', Paper presented at the Annual Meeting of the Academy of Management, Denver, Colorado.

Wattanavitukul, P. (2002) 'Hai Gui: The Sea Turtles Come Marching Home’, Shanghai: P. W.

Willer, R. and Willer. D. (2000) 'Exploring Dynamic Networks: Hypotheses and Conjectures', Social Networks 22: 251-272.

Xin, K. and Pearce, J. (1996) 'Guanxi: Connections as Substitutes for Formal Institutional Support', Academy of Management Journal 39: 1641-1658.

Yang, M. (1994) Gifts, favors and banquets: The art of social relationships in China, Cornell University Press: Ithaca, NY.

Zeggelink, E. (1994) 'Dynamics of Structure: An Individual Oriented Approach', Social Networks. 16: 295-333. 
Table 1. Firms by Business in 2001 and 2002

\begin{tabular}{|c|c|c|c|c|}
\hline & & $\begin{array}{c}2001 \\
\mathrm{n}=94 \\
\text { (total) }\end{array}$ & $\begin{array}{c}2001 \\
\mathrm{n}=52 \\
\text { (re-interviewed) }\end{array}$ & $\begin{array}{c}2002 \\
n=52 \\
\text { (re-interviewed) }\end{array}$ \\
\hline 1 & $\begin{array}{l}\text { Internet service } \\
\text { provider }\end{array}$ & 14 & 7 & 7 \\
\hline 2 & $\begin{array}{l}\text { Internet content } \\
\text { provider }\end{array}$ & 36 & 18 & 14 \\
\hline 3 & E-commerce & 29 & 15 & 10 \\
\hline 4 & $\begin{array}{l}\text { Networking } \\
\text { technology }\end{array}$ & 16 & 8 & 5 \\
\hline 5 & Software development & 33 & 16 & 8 \\
\hline 6 & Equipment distributor & 5 & 3 & 6 \\
\hline 7 & Other Internet related & 13 & 7 & 6 \\
\hline
\end{tabular}


Table 2. Means, Standard Deviations and Pearson's Correlations $(\mathbf{N}=52)$

\begin{tabular}{|c|c|c|c|c|c|c|c|c|c|}
\hline & Variables & $\mathrm{M}$ & S.D & 1 & 2 & 3 & 4 & 5 & 6 \\
\hline 1 & Structural holes 2001 & 6.76 & 5.30 & & & & & & \\
\hline 2 & Officials 2001 (\%) & 0.11 & 0.16 & .02 & & & & & \\
\hline 3 & Networking skills 2001 & 3.02 & 0.61 & $\begin{array}{c}- \\
.38^{*} \\
*\end{array}$ & .01 & & & & \\
\hline 4 & Networking skills 2002 & 0.49 & 0.98 & .24 & -.13 & $\begin{array}{c}- \\
.61^{*} \\
*\end{array}$ & & & \\
\hline 5 & Structural holes 2002 & 0.20 & 5.52 & $\begin{array}{c}- \\
.91 * \\
*\end{array}$ & -.03 & $\begin{array}{c}.43^{*} \\
*\end{array}$ & -.27 & & \\
\hline 6 & $\begin{array}{l}\text { Venture capital (in } \\
\text { thousand US\$) }\end{array}$ & 192.1 & 455 & $.33 *$ & -.08 & -.16 & .07 & $-.29 *$ & \\
\hline 7 & Investors 2002 & 0.01 & 0.56 & -.04 & .03 & -.15 & $.27 *$ & .06 & -.04 \\
\hline 8 & Project partners 2002 & 0.35 & 0.77 & .16 & -.06 & -.03 & -.03 & -.08 & .19 \\
\hline 9 & Western experience (years) & 0.88 & 2.02 & .21 & .09 & -.03 & -.12 & -.12 & -.12 \\
\hline 10 & Startup experience & 0.37 & 0.49 & -.04 & .25 & .22 & -.13 & .01 & .13 \\
\hline 11 & Internet experience (years) & 1.94 & 3.54 & -.21 & .07 & .18 & -.08 & .21 & -.11 \\
\hline 12 & Firm age (years) & 2.67 & 2.18 & -.08 & -.04 & -.23 & .16 & .03 & -.14 \\
\hline 13 & $\begin{array}{l}\text { Firm size (number of } \\
\text { employees) }\end{array}$ & 41.69 & 61.76 & $.41^{*}$ & -.05 & -.21 & .23 & $-.36 *$ & .12 \\
\hline 14 & $\begin{array}{l}\text { Internet service and content } \\
\text { providers }\end{array}$ & .39 & .49 & .13 & -.09 & -.09 & -.07 & -.11 & .06 \\
\hline 15 & E-commerce firms & .19 & .40 & -.06 & .25 & .22 & -.18 & .03 & -.13 \\
\hline 16 & Software firms & .15 & .36 & .04 & .01 & .07 & .07 & .01 & .01 \\
\hline 17 & Other Internet related firms & .25 & .44 & -.12 & -.14 & -.16 & .18 & .08 & .04 \\
\hline
\end{tabular}

${ }_{*}^{*} \mathrm{p}<0.05$ 
Table 2. Means, Standard Deviations and Pearson's Correlations (Continued)

\begin{tabular}{|c|c|c|c|c|c|c|c|c|c|c|c|}
\hline & Variables & 7 & 8 & 9 & 10 & 11 & 12 & 13 & 14 & 15 & 16 \\
\hline 8 & Project partners 2002 & .02 & & & & & & & & & \\
\hline 9 & $\begin{array}{l}\text { Western experience } \\
\text { (years) }\end{array}$ & -.11 & .11 & & & & & & & & \\
\hline 10 & Startup experience & .03 & -.09 & -.01 & & & & & & & \\
\hline 11 & Internet experience (years) & -.13 & -.01 & -.03 & .18 & & & & & & \\
\hline 12 & Firm age (years) & .06 & $\begin{array}{r}.01 \\
1\end{array}$ & .01 & $\begin{array}{r}- \\
.29 \\
*\end{array}$ & -.05 & & & & & \\
\hline 13 & $\begin{array}{l}\text { Firm size (number of } \\
\text { employees) }\end{array}$ & .03 & .18 & -.04 & -.04 & .05 & $\begin{array}{l}.45 \\
* *\end{array}$ & & & & \\
\hline 14 & $\begin{array}{l}\text { Internet service and } \\
\text { content providers }\end{array}$ & .10 & -.03 & .04 & .04 & -.13 & .11 & .01 & & & \\
\hline 15 & E-commerce firms & .10 & -.09 & -.02 & -.07 & .06 & -.10 & -.12 & $\begin{array}{r}- \\
.38 \\
* *\end{array}$ & & \\
\hline 16 & Software firms & -.06 & .01 & .07 & .22 & $\begin{array}{r}.29 \\
*\end{array}$ & -.12 & .02 & $\begin{array}{r}- \\
.34 \\
*\end{array}$ & -.21 & \\
\hline 17 & $\begin{array}{l}\text { Other Internet related } \\
\text { firms }\end{array}$ & -.16 & .08 & -.1 & -.17 & -.14 & .07 & .09 & $\begin{array}{r}- \\
.47 \\
* *\end{array}$ & $\begin{array}{r}- \\
.28 \\
*\end{array}$ & -.25 \\
\hline
\end{tabular}


Table 3. Logistic Regression Analysis Predicting Firm Survival in 2002 (N=81)

\begin{tabular}{|c|c|c|c|c|c|}
\hline & Model 1 & Model 2 & Model 3 & Model 4 & Model 5 \\
\hline \multicolumn{6}{|l|}{ Controls } \\
\hline Firm age & -.05 & -.08 & -.09 & -.14 & -.21 \\
\hline Firm size & .01 & .01 & .01 & .01 & .01 \\
\hline Venture capital & .01 & .01 & .01 & .01 & .01 \\
\hline Project partners 2001 & 1.19 & $1.35^{*}$ & $1.02 \pi$ & $1.26 *$ & $2.07 *$ \\
\hline Officials 2001 & -1.43 & -.67 & -.73 & -1.19 & -3.37 \\
\hline $\begin{array}{l}\text { Internet service and content } \\
\text { provider }\end{array}$ & -.96 & -.9 & -.74 & -1.36 & -1.51 \\
\hline E-commerce & -1.12 & -.99 & -1.14 & -1.39 & -1.25 \\
\hline Software & $-2.01 *$ & -1.26 & -1.559 & $-2.21 *$ & $-2.89 *$ \\
\hline \multicolumn{6}{|l|}{ Main effects } \\
\hline Structural holes 2001 & .11 & .159 & .12 & .06 & .16 \\
\hline Startup experience & 1.029 & $2.43^{*}$ & & & $3.32 *$ \\
\hline Internet experience & .26 & & .48 & & .64 \\
\hline Western experience & $.57 *$ & & & $.68 \pi$ & .719 \\
\hline \multicolumn{6}{|l|}{ Interaction effects } \\
\hline $\begin{array}{l}\text { Startup experience X } \\
\text { Structural holes } 2001\end{array}$ & & -.26 & & & -.429 \\
\hline $\begin{array}{l}\text { Internet experience X } \\
\text { Structural holes } 2001\end{array}$ & & & .03 & & -.06 \\
\hline $\begin{array}{l}\text { Western experience X } \\
\text { Structural holes } 2001\end{array}$ & & & & $.27^{*}$ & $.41^{* *}$ \\
\hline$-2 L L$ & 79.61 & 87.78 & 86.49 & 78.28 & 64.98 \\
\hline Chi-square & $25.16^{*}$ & 17.19 & $18.27 \rrbracket$ & $26.48 * *$ & $39.79 * * *$ \\
\hline
\end{tabular}

Values represent B coefficients.

Ip $<0.1 ;{ }^{*} \mathrm{p}<0.05 ;{ }^{* *} \mathrm{p}<0.01 ;{ }^{* * *} \mathrm{p}<0.001$ 
Table 4. Linear Regression Analysis Predicting Network Dynamics, and Firm Legitimacy in $2002(\mathrm{~N}=52)$

\begin{tabular}{|c|c|c|}
\hline & $\begin{array}{c}\text { Structural holes } \\
2002 \\
\end{array}$ & Investors 2002 \\
\hline & Model 1 & Model 2 \\
\hline \multicolumn{3}{|l|}{ Controls } \\
\hline Firm age & .279 & .01 \\
\hline Firm size & $-.41 * *$ & -.02 \\
\hline Venture capital & -.15 & -.05 \\
\hline $\begin{array}{l}\text { Project partners } \\
2002\end{array}$ & .01 & .08 \\
\hline Officials 2001 & -.03 & .03 \\
\hline $\begin{array}{l}\text { Internet service and } \\
\text { content providers }\end{array}$ & -.21 & .27 \\
\hline E-commerce & -.19 & $.28 \pi$ \\
\hline Software & -.08 & .06 \\
\hline \multicolumn{3}{|l|}{ Predictors } \\
\hline $\begin{array}{l}\text { Networking skills } \\
2001\end{array}$ & $.41^{* *}$ & \\
\hline $\begin{array}{l}\text { Networking skills } \\
2002\end{array}$ & & $.36 *$ \\
\hline Model F & $3.1^{* *}$ & .91 \\
\hline Adjusted R square & .26 & .02 \\
\hline
\end{tabular}

Values represent standardized B coefficients.

Ip $<0.1$

$* \mathrm{p}<0.05$

$* * \mathrm{p}<0.01$

$* * * \mathrm{p}<0.001$ 


\section{Appendix: Name Generator Questions}

I borrowed questions that capture structural holes from the short-form of the sociometric questionnaire developed at the University of Chicago's Graduate School of Business to measure the social capital of managers and other professionals. The questionnaire is available from the web-site (http://gsb.chicago.edu/fac/ronald.burt). In total, 6 questions were asked to generate names: 1. Considering all of the professional contacts you have made in your career so far, who have been most valued contacts in the sense that they were the most important to your achievements? 2. Shifting to a broader view of your network, consider the people with whom you like to spend your free time. Over the last six months, who are the two or three people you have been with most often for informal social activities such as going out to lunch, dinner, drinks, films, visiting one another's homes, and so on? 3. From time to time, most people discuss important matters with other people, people they trust. The range of important matters varies from person to person across work, leisure, family, politics, whatever. The range of relations varies across work, family, friends, and advisors. If you look back over the last six months, who are the three or four people with whom you discussed matters important to you? 4 . What is first name and last initial of your spouse or person with whom you are living as if married. Spouse was excluded in the final analysis. 5. Please list (table was presented) - up to a maximum of 20 names -each person named in the preceding questions. This question has generated a full list of names.

Finally, respondents were asked to describe the connection between each pair of contacts as especially close, distant or something intermediate. This question captures structural holes in personal networks. The wording is as follows: The next task is to describe the strength of relations between listed people. You do this by circling codes in the matrix below (Matrix table was included in the questionnaire). This is a complex question, but it is essential to measuring social capital - and answering the question is a simple task when taken one column at a time. Begin with the first person listed. Relations with the first person are listed in the first column. Indicate his or her relationship with the person in each row in one of three ways: Circle EC if there is an ESPECIALLY CLOSE relation between the row person and the first person (like this: D. (EC); Circle D if there the row person and first person are DISTANT in the sense that they rarely work together, are total strangers as far as you know, or do not enjoy one another's company (like this: (D). EC; Leave D..EC blank to indicate that two people neither distant nor especially close. 


\section{DAVIDSON INSTITUTE WORKING PAPER SERIES - Most Recent Papers}

The entire Working Paper Series may be downloaded free of charge at: www.wdi.bus.umich.edu

CURRENT AS OF 2/15/05

\begin{tabular}{|c|c|c|}
\hline Publication & Authors & Date \\
\hline $\begin{array}{l}\text { No. 753: Internet Entrepreneurship: Networks and Performance of } \\
\text { Internet Ventures In China }\end{array}$ & Bat Batjargal & Feb. 2005 \\
\hline $\begin{array}{l}\text { No. 752: Network Triads: Transitivity, Referral and Venture Capital } \\
\text { Decisions in China and Russia }\end{array}$ & Bat Batjargal & Feb. 2005 \\
\hline $\begin{array}{l}\text { No. 751: Software Entrepreneurship: Knowledge Networks and } \\
\text { Performance Of Software Ventures In China and Russia }\end{array}$ & Bat Batjargal & Feb. 2005 \\
\hline $\begin{array}{l}\text { No. 750: Retained State Shareholding in Chinese PLCs: Does } \\
\text { Government Ownership Reduce Corporate Value? }\end{array}$ & Lihui Tian and Saul Estrin & Feb. 2005 \\
\hline No. 749: Financial Development and Technology & Solomon Tadesse & Feb. 2005 \\
\hline No. 748: Banking Fragility and Disclosure: International Evidence & Solomon Tadesse & Feb. 2005 \\
\hline $\begin{array}{l}\text { No. 747: Consolidation, Scale Economies and Technological Change in } \\
\text { Japanese Banking }\end{array}$ & Solomon Tadesse & Feb. 2005 \\
\hline $\begin{array}{l}\text { No. 746: Trade Creation and Diversion Effects of Europe’s Regional } \\
\text { Liberalization Agreements }\end{array}$ & Yener Kandogan & Feb. 2005 \\
\hline No. 745: Quality of Institutions, Credit Markets and Bankruptcy & Christa Hainz & Feb. 2005 \\
\hline $\begin{array}{l}\text { No. 744: How Transition Paths Differ: Enterprise Performance in Russia } \\
\text { and China }\end{array}$ & Sumon Bhaumik and Saul Estrin & Jan. 2005 \\
\hline $\begin{array}{l}\text { No. 743: Inflation Targeting, Between Rhetoric and Reality. The Case } \\
\text { of Transition Economies }\end{array}$ & Daniel Daianu and Laurian Lungu & Jan. 2005 \\
\hline $\begin{array}{l}\text { No. 742: How Does Law Affect Finance? An Empirical Examination of } \\
\text { Tunneling in an Emerging Market }\end{array}$ & $\begin{array}{l}\text { Vladimir Atanasov, Conrad S. } \\
\text { Ciccotello, \& Stanley B. Gyoshev }\end{array}$ & Jan. 2005 \\
\hline $\begin{array}{l}\text { No. 741: Do Insider Trading Laws Matter? Some Preliminary } \\
\text { Comparative Evidence }\end{array}$ & Laura Nyantung Beny & Jan. 2005 \\
\hline $\begin{array}{l}\text { No. 740: Autopsy on an Empire: Understanding Mortality in Russia and } \\
\text { the Former Soviet Union }\end{array}$ & $\begin{array}{l}\text { Elizabeth Brainerd and David M. } \\
\text { Cutler }\end{array}$ & Jan. 2005 \\
\hline $\begin{array}{l}\text { No. 739: Not Separate, Not Equal: Poverty and Inequality in Post- } \\
\text { Apartheid South Africa }\end{array}$ & $\begin{array}{l}\text { Johannes G. Hoogeveen and Berk } \\
\text { Özler }\end{array}$ & Jan. 2005 \\
\hline $\begin{array}{l}\text { No. 738: The Marketing Structure in Agribusiness during the Transition } \\
\text { in Bulgaria }\end{array}$ & $\begin{array}{l}\text { Steve Murray, Yordan Staykov, } \\
\text { and Valentin Katzerov }\end{array}$ & Jan. 2005 \\
\hline No. 737: Passive Creditors & $\begin{array}{l}\text { Koen Schoors and Konstantin } \\
\text { Sonin }\end{array}$ & Jan. 2005 \\
\hline $\begin{array}{l}\text { No. 736: From a currency board to the euro: Public attitudes toward } \\
\text { unilateral euroization in Bulgaria }\end{array}$ & Neven T. Valev & Jan. 2005 \\
\hline No. 735: Dictators and Their Viziers: Agency Problems in Dictatorships & $\begin{array}{l}\text { Georgy Egorov and Konstantin } \\
\text { Sonin }\end{array}$ & Jan. 2005 \\
\hline $\begin{array}{l}\text { No. 734: Foreign Investment, Corporate Ownership, and Development: } \\
\text { Are Firms in Emerging Markets Catching Up to the World Standard? }\end{array}$ & $\begin{array}{l}\text { Klara Sabirianova, Jan Svejnar, } \\
\text { and Katherine Terrell }\end{array}$ & Jan. 2005 \\
\hline $\begin{array}{l}\text { No. 733: Businessman Candidates: Special-Interest Politics in Weakly } \\
\text { Institutionalized Environments }\end{array}$ & $\begin{array}{l}\text { Scott Gehlbach and Konstantin } \\
\text { Sonin }\end{array}$ & Dec. 2004 \\
\hline $\begin{array}{l}\text { No. 732: Measuring the Institutional Change of the Monetary Regime } \\
\text { in a Political Economy Perspective }\end{array}$ & $\begin{array}{l}\text { Nikolay Nenovsky and Yorgos } \\
\text { Rizopoulos }\end{array}$ & Dec. 2004 \\
\hline $\begin{array}{l}\text { No. 731: Impact of Regulated Price Adjustments on Price Variability in } \\
\text { a Very Low Inflation Transition Economy: Case of Armenia }\end{array}$ & Aghassi Mkrtchyan & Nov. 2004 \\
\hline $\begin{array}{l}\text { No. 730: Reform, FDI and Economic Growth: Tale of the Tortoise and } \\
\text { the Hare }\end{array}$ & $\begin{array}{l}\text { Bruno Merlevede and Koen } \\
\text { Schoors }\end{array}$ & Nov. 2004 \\
\hline $\begin{array}{l}\text { No. 729: The Effects of Transition and Political Instability On Foreign } \\
\text { Direct Investment Inflows: Central Europe and the Balkans }\end{array}$ & $\begin{array}{l}\text { Josef C. Brada, Ali M. Kutan, } \\
\text { and Taner M. Yigit }\end{array}$ & Nov. 2004 \\
\hline $\begin{array}{l}\text { No. 728: Institutional Distance and International Business Strategies } \\
\text { in Emerging Economies }\end{array}$ & $\begin{array}{l}\text { Delia Ionascu, Klaus E. Meyer, } \\
\text { and Saul Erstin }\end{array}$ & Nov. 2004 \\
\hline No. 727: Explaining Patterns of Corruption in the Russian Regions & $\begin{array}{l}\text { Phyllis Dininio and Robert W. } \\
\text { Orttung }\end{array}$ & Nov. 2004 \\
\hline $\begin{array}{l}\text { No. 726: The Politics of Institutional Learning and Creation: Bank } \\
\text { Crises and Supervision in East Central Europe }\end{array}$ & Gerald A. McDermott & Nov. 2004 \\
\hline
\end{tabular}

